\title{
Effect of added bovine casein and whey protein on the quality of camel and bovine milk yoghurts
}

\author{
Bhawna Sobti, Hajer A. A. Al Teneiji, Afaf Kamal-Eldin* \\ Department of Food, Nutrition and Health, United Arab Emirates university, P.O. Box 15551, Al-Ain, UAE
}

\section{A B S T R A C T}

\begin{abstract}
The aim of this study is to evaluate the effect of fortification of camel milk (CM) and bovine milk (BM) with 1-4\% of bovine casein (CN) and/or whey protein (WP) on the quality of yoghurts after 12 hours of fermentation. Response surface methodology was used to design the experiment. Yoghurts were evaluated for $\mathrm{pH}$, acidity, hardness and rheology. The results revealed that addition of WP and CN significantly improved the hardness $(p<0.000)$, and the rheological properties; storage modulus $\left(G^{\prime}, p<0.005\right)$, and loss modulus ( $\left.G^{\prime \prime}, p<0.005\right)$, viscosity $(p<0.005)$ and $\tan \delta\left(\mathrm{G}^{\prime \prime} / \mathrm{G}^{\prime}, \mathrm{p}<0.05\right)$ of $\mathrm{CM}$ yoghurts. Both types of yoghurts attained highest viscosity, $\mathrm{G}^{\prime}$ and $\mathrm{G}^{\prime \prime}$ values at highest level of WP $(4 \%)$ and intermediate level of $\mathrm{CN}(2.5 \%)$ while increased CN ratio showed negative effects on yoghurts rheology. It can be concluded that the amount of total proteins as well as altering $\mathrm{CN}$-to-WP ratio are important for the formation of strong gel network and the production of good quality set yoghurts.
\end{abstract}

Keywords: Yoghurt; Camel milk; Bovine milk; Texture; Rheology

\section{INTRODUCTION}

Fresh and fermented camel milks (CM) is gaining increasing importance worldwide as a healthy alternative to bovine milk (BM) (Technavo, 2018). CM is claimed to possess a number of therapeutic properties including anti-diabetic (Agrawal et al., 2007, Mirmiran et al., 2017, Ayoub et al., 2018), anti-carcinogenic (Magjeed, 2005), and anti-hypertensive effects (Quan et al., 2008) and has been recommended to be consumed by children who are allergic to bovine milk (El-Agamy et al., 2009). However, the exploitation of CM faces challenges because of difficulties in processing by conventional technologies used in the processing of bovine milk as well as some sensory limitations (Ghnimi et al., 2015; Haliu et al., 2016; Berhe et al., 2017).

Yoghurt is a popular fermented dairy product widely consumed by people all over the world. It is prepared by adding starter cultures (mainly Streptococcus spp. and Lactobacilli $s p$.) to heat-treated milk to allow fermentation of caseins $(\mathrm{CN})$ to become unstable at their isoelectric point ( $\mathrm{pH} 4.6$ in bovine milk) and to coagulate forming different networks (Damin et al., 2009). Heat treatment of milk above $70{ }^{\circ} \mathrm{C}$ prior fermentation allows the denaturation of the global whey proteins (WP) and the formation of disulfide bonds between $\beta$-lactoglobulin ( $\beta-\mathrm{LG}$ ) and $\mathrm{k}$-casein $(\mathrm{K}-\mathrm{CN})$ leading to firm gels (Lucey et al., 1998; Guyomarc'h et al., 2003; Anema, 2006). This bond formation depends upon number of factors including protein concentrations, $\mathrm{pH}$, time, and temperature (Oldfield et al., 1998).

For a fermented product like yoghurt, texture is a very important attribute that affects its quality, consumer acceptability and commercial production. In comparison to $\mathrm{BM}$, it is difficult to produce fermented products with good texture and rheology from CM (Attia et al., 2001), which only forms weak gels more preferable for drinking (Al haj \& Al Kanhal, 2010). Mohamed et al. (1990) also reported that CM failed to reach a gel-like structure even after $18 \mathrm{~h}$ incubation with lactic acid cultures. The inability of camel milk to form hard viscous gels is mainly attributed to its lack of $\beta$-lactoglobulin and lower amounts of $\mathrm{K}$-casein (Kappeler et al., 1998); and high whey protein to casein ratio (Shamsia, 2009). $\beta$-Lactoglobulin and $\mathrm{k}$-casein are essential for gel formation due to interactions among them and between them and other milk proteins (Donato \& Guyomarc'H, 2009). It was found that the texture and rheology of bovine yoghurts can be improved by dry matter fortification,

\footnotetext{
*Corresponding author:

Prof. Afaf Kamal-Eldin, Department of Food, Nutrition and Health, United Arab Emirates university, P.O. Box 15551, Al-Ain, UAE.

Tel.: 00971501390248. E-mail: Afaf.kamal@uaeu.ac.ae
} 
e.g. by the addition of dairy ingredients such as skim milk powder, whey proteins, caseins, and caseinates (Sodini and Béal, 2003; Damin et al., 2009; Peng et al., 2009). Herrero and Requena (2006) also reported that the addition of whey protein concentrate enhanced the textural properties of goat milk yoghurts. Increasing the levels of denatured whey proteins showed significant effects on reducing gelation time, increasing gelation $\mathrm{pH}$ after acidification, and improving the hardness of yoghurt gels (Lucey et al., 1999). Puvanenthiran, (2002) also demonstrate the positive effect of altering $\mathrm{CN}$ : WP ratio on the yield stress of set yoghurts by fortification either with whey protein isolate or sodium caseinates. The present study was undertaken to explore the effect of fortification of camel milk with bovine caseins and whey proteins on $\mathrm{pH}$, acidity, texture, and rheology of $\mathrm{CM}$ yoghurts in comparison with BM yoghurts.

\section{MATERIAL AND METHODS}

\section{Materials}

Camel milk powder (Al Ain Dairy, Al Ain, UAE) and cow milk powder (Nido, Nestle, Dubai) were purchased from the local supermarkets in Al Ain, UAE. Yoghurts were prepared using lyophilized starter culture YoFlex ${ }^{\circledR E x p r e s s}$ 1.0, containing Streptococcus thermophilus and Lactobacillus delbruekii ssp. bulgaricus in the ratio of 1:1 (w/w) (ChrisHansen, Denmark). Bovine casein (CN) (Gold Standard 100\% Casein, Downers Grove, IL, USA) and whey protein isolate (WP) (About Time, Pittsburgh, PA, USA) were purchased from local market of Alain, UAE.

\section{Yoghurt preparation}

Yoghurt samples were prepared from bovine and camel milk powders by dissolving $25 \mathrm{~g}$ of powder in $200 \mathrm{ml}$ of water according to manufacturer's instructions. Indigenous level of WP present in reconstituted BM and CM was 1.8\% and $1.375 \%$ while indigenous level of $\mathrm{CN}$ was $1.437 \%$ and $1.27 \%$, respectively. Commercial whey protein isolate (WP) at $1-4 \%$ and bovine casein $(\mathrm{CN})$ at $1-4 \%$ was added to both milks before pasteurization at $85{ }^{\circ} \mathrm{C}$ for $15 \mathrm{~min}$. Total WP and $\mathrm{CN}$ at five different levels in both yoghurts, $\mathrm{CN}(1.63-6.06 \%)$ and whey proteins (1.75-6.42\%). The footnote of (Table 1) has the details for five levels of WP and $\mathrm{CN}$ in yoghurt samples. Milk samples were fermented with the bacterial starter culture vi\%. S. thermophilus and L. delbrueckii ssp. Bulgaricus. The level of the starter culture was $0.05 \%$ for camel milk and $0.025 \%$ for bovine milk and the fermentation was performed at $43{ }^{\circ} \mathrm{C}$ for $12 \mathrm{hrs}$.

\section{Titratable acidity and $\mathrm{pH}$}

The titrable acidity of the samples was estimated using standard method ISO/TS 11869:2012 (IDF/RM 150:2012) and the $\mathrm{pH}$ was determined using a digital $\mathrm{pH}$ meter (OHAUS Europe Gmbh, Greifensee, Switzerland).

\section{Texture profile analysis (TPA)}

The hardness of the yoghurt samples were determined using Brookfield texture analyzer-CT III (Middleboro, MA, USA) equipped with a $4.5 \mathrm{~kg}$ load cell. TPA was carried out by a compression test that generated a plot of force (g) versus time (s) in one complete run. A 25-mm-diameter perplex cylindrical probe (TA11/1000) with a test speed of $1 \mathrm{~mm} / \mathrm{s}$ and $3 \mathrm{~mm}$ of target distance was used to measure the textural profile of the yogurt samples and their hardness was calculated by the software program of the equipment.

\section{Dynamic rheology}

Rheological measurements were carried out using Discovery HR-3 rheometer (TA Instruments, New Castle, DE, USA) with a cone-plate geometry, in which the rotating cone was $60 \mathrm{~mm}$ in diameter and the cone angle was $4^{\circ}$ with a gap of $225 \mu \mathrm{m}$. Oscillatory rheology (frequency sweep) tests were carried out at $30{ }^{\circ} \mathrm{C}$ at the same deformation $(1 \%)$ and frequencies ranging from 0.01 to $10.0 \mathrm{~Hz}$. The storage modulus (elastic modulus G'), the loss modulus (viscous modulus, G") and the apparent viscosity $\eta^{*}(\mathrm{~Pa} . \mathrm{s})$ were determined by the equipment software in all cases. The loss tangent, or $\tan \delta$, was calculated as $G$ " $/ G^{\prime}$.

\section{Statistical design and analysis}

All statistical analyses were completed using a computer software package (Minitab 18, Minitab Inc., State College, PA, USA). Thirteen experiments were performed as per Central Composite rotatable design (CCRD) with two independent variables (WP and $\mathrm{CN}$ ) and five levels of each variable. The CCRD design was used to estimate the effect of the addition of WP and $\mathrm{CN}$ on $\mathrm{pH}$, acidity, texture and rheology. All 13 experiments were repeated three times and each analysis was performed in triplicate. Each response was fitted to a quadratic polynomial model as per the following equation

$$
y=\beta_{0}+\sum_{i=1}^{4} \beta_{i} x_{i}+\sum_{i=1}^{4} \beta_{i i} x_{i}^{2}+\sum_{i=1}^{3} \sum_{j=i+1}^{4} \beta_{i j} x_{i} x_{j}
$$

Where $y$ is the response, $\beta_{0}$ is constant, $\beta_{\mathrm{i}}$ is the linear coefficient, $\beta_{\mathrm{ii}}$ is the quadratic coefficient and $\beta_{\mathrm{ij}}$ is the interaction coefficient. $X_{i}$ and $X_{i}$ are independent variables. The level of significance used in this study was $\mathrm{p}<0.05$ or lower.

\section{RESULTS AND DISCUSSION}

\section{The characteristics of pure camel and bovine milk yoghurts}

Fig. 1 presents photos of the yoghurts obtained from pure bovine and camel milks prepared as discussed above. The pure camel milk (CM) yoghurt has a soft liquidly texture compared to the set bovine milk (BM) yoghurt. The acidity, 


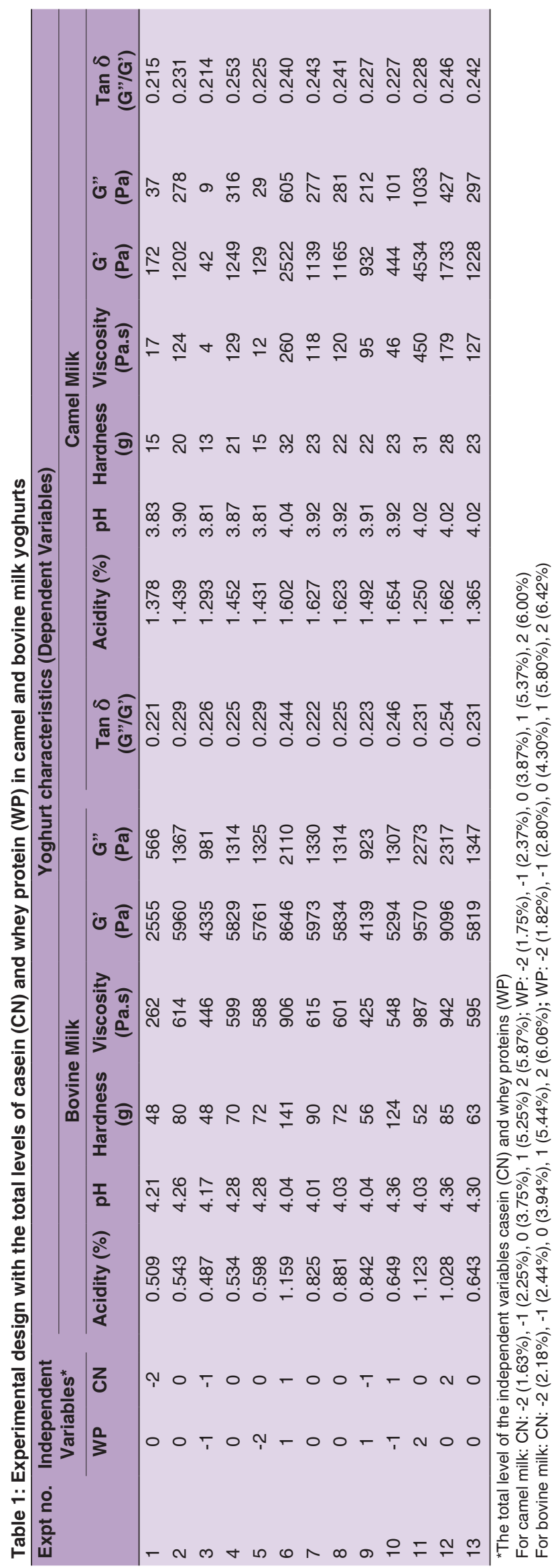

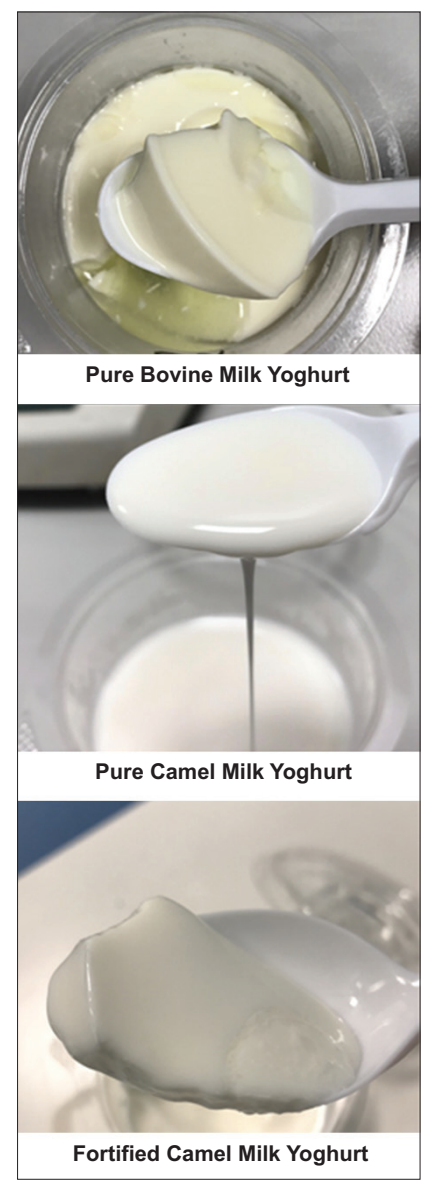

Fig 1. Photographs showing the appearance of yoghurts from pure bovine milk, pure camel milk, and camel milk fortified with whey protein $(4 \%)$ and casein $(2.5 \%)$.

$\mathrm{pH}$, textural and rheological properties of the two type yoghurts are presented in (Table 2). Pure CM yoghurt was found to be more acidic and lower in $\mathrm{pH}$ than the pure $\mathrm{BM}$ yoghurt. The decrease in $\mathrm{pH}$ follows the increase in titratable acidity caused by the microbial activity converting lactose to lactic acid (Attia et al., 2001; Prasanna et al., 2013, Costa and Conte-Junior, 2015; Costa et al., 2016). The difference in $\mathrm{pH}$ between the $\mathrm{CM}$ and $\mathrm{BM}$ yoghurts was attributed to differences in buffering capacities and proteolytic activity (Attia et al., 2001; Al-Sheraji et al., 2013). Pure CM yoghurt showed extremely lower hardness, viscosity, storage modulus $\left(G^{\prime}\right)$ and loss modulus (G”) values compared to pure BM yoghurt supporting the liquid consistency and weak gel structure (Table 2). Since the storage modulus is responsible for strength and number of bonds in a network (Roefs et al., 1990; van Vliet et al., 1991), the results obtained here indicate lower number of bonds in the CM yoghurt gel network compared to those in $\mathrm{BM}$ yoghurt gels.

The weak body and poor texture of fermented CM yoghurts may be attributed to several factors; primarily to the lack of $\beta$-LG (El-Agamy et al., 2009) and the low concentration 
Table 2: The characteristics of yoghurts made of pure camel milk (CM) versus pure bovine milk (BM)*

\begin{tabular}{lcc}
\hline Parameters & Pure BM yoghurt & Pure CM yoghurt \\
\hline Acidity (\%) & $0.08 \pm 0.07$ & $1.2 \pm 0.03^{\star *}$ \\
pH & $4.3 \pm 0.05$ & $3.7 \pm 0.04^{* *}$ \\
Hardness (g) & $52.5 \pm 4.33$ & $11.8 \pm 0.29^{\star * *}$ \\
Viscosity (Pa.s) & $661 \pm 22$ & $0.57 \pm 0.08^{\star * *}$ \\
G'(Pa) & $6425 \pm 215$ & $5.5 \pm 0.78^{\star * *}$ \\
G" $(\mathrm{Pa})$ & $1461 \pm 74$ & $1.3 \pm 0.17^{\star * *}$ \\
Tan $\delta\left(G^{\prime \prime} / G^{\prime}\right)$ & $0.227 \pm 0.004$ & $0.243 \pm 0.004^{*}$ \\
\hline
\end{tabular}

*Means and standard deviations of three preparations.

Yoghurt from CM is significantly different from BM: ${ }^{*} \mathrm{p}<0.01$, ${ }^{\star *} \mathrm{p}<0.001$, and ${ }^{* * *} \mathrm{p}<0.0001$

of $\mathrm{k}-\mathrm{CN}$ (Kappeler, 1998) and secondarily to the different molecular structures of the proteins (Shamsia, 2009), and the large size of casein micelles (Kamal et al., 2017). It is believed that disulfide bonding between $\beta$-LG and $\mathrm{K}-\mathrm{CN}$ during the heat treatment preceding fermentation is essential for firm yoghurt structure. Thus, fortification of milk with $\mathrm{CN}$ and WP was foreseen to be important for enhancing the functional and nutritional properties and preventing textural defects such as poor gel firmness and syneresis (Sodini and Béal, 2003; Séverin and Wenshui, 2005; Marafon et al., 2011).

\section{Effect of addition of WP and CN on characteristics of fortified CM and BM yoghurts}

(Table 1) presents the effects of fortification of CM versus BM with different levels of WP and CN (range 1-4\%) on yoghurt characteristics, namely acidity (\%), $\mathrm{pH}$, hardness (g), viscosity (Pa.s), G' (Pa) and G" (Pa). The endogenous levels of CN and WP were: $1.8 \%$ and $1.4 \%$ in BM; and 1.2 $\%$ and $1.4 \%$ in CM, respectively. The regression coefficients obtained by multiple regression fitting of the response variables (titrable acidity, $\mathrm{pH}$, hardness, viscosity, G', G', and $\tan \delta$ ) to the levels of the independent variables (total $\mathrm{CN}$ and total WP) by the quadratic (or cubic) models are presented in (Table 3). This analysis shows that CM yoghurts start with higher acidity and low $\mathrm{pH}$ compared to $\mathrm{BM}$ yoghurts and that the fortification with WP and $\mathrm{CN}$ has opposing effects on the acidity of $\mathrm{CM}$ yoghurt and the $\mathrm{pH}$ of BM yoghurts leading to non-significant overall models. Peng et al. (2009) published similar findings on the CNfortification of BM yoghurts showing increased buffering capacity, i.e. resistance to $\mathrm{pH}$ change, at around $\mathrm{pH} 5$.

Hardness and rheology are important textural characteristics for set-type yoghurts as they are important quality parameters in consumer acceptability. (Table 3) shows a large difference between CM and BM yoghurts in their initial hardness, viscosity, G', G', and $\tan \delta$ and how these are affected by the addition of WP and CN. The fortification with WP significantly increased the hardness in CM yoghurts as well as the viscosity, G', and G" in both $\mathrm{CM}$ and BM yoghurts $(\mathrm{p}<0.01)$ without effects on $\tan \delta$. This can be explained by formation of high level of crosslinking within the gel network on fortifying the yogurt mix with WP, thereby increasing the viscosity of samples (Remeuf et al., 2003). The interaction effects of WP, i.e. WP*WP, were positive in both $\mathrm{CM}$ and $\mathrm{BM}$ yoghurts but not significant. The addition of $\mathrm{CN}$ had positive effects on the hardness, viscosity, G', G', and tan $\delta$ in both $\mathrm{CM}$ and $\mathrm{BM}$ yoghurts $(\mathrm{p}<0.05)$ but the interaction effect, $\mathrm{CN} * \mathrm{CN}$, was negative but insignificant in the case of CM yoghurts' hardness, viscosity, G', and G' and BM yoghurts' viscosity, G', and G'. Although non-significant, the interactions within WP and between WP and CN lead to increased viscosity, G', and G" in CM and BM yoghurts. On the other hand, interactions within $\mathrm{CN}$ contributed negatively, but insignificantly, to the viscosity, G', and G' in CM and BM yoghurts (Table 3). Because of these negative interactions, the optimum concentration of $\mathrm{CN}$ in all yoghurts was about $2.5 \%$ (Fig. 2). Interactions between the additives and the indigenous proteins and other components of the milks are included in the constant of the models, which were found highly significant suggesting that these "unknown" interactions play very important roles. Despite large effects of added WP and CN on viscosity, G', and G" of fortified compared to pure CM yoghurts, they did not alter the tan $\delta$ values (i.e. G"/G') indicating no change in the gel-to-liquid behavior despite the change in hardness and viscosity. This is desired for the consistency of yoghurt.

The effects of WP and CN addition is complicated by their contribution to the content of total solids (TS) and the effect of TS on the hardness of two yoghurts showing a strong and significant correlation between TS and the hardness of CM yoghurts and on the rheology of CM and BM yoghurts (Fig. 3). Ibrahem and Zubeir (2016) also documented similar findings on yoghurt prepared from camel-sheeps' milk mixtures with improved texture owing to its have higher total solids, fat and protein content than in comparison to those obtained from CM alone. These results are in agreement with Anema et al. (2006) who also explained the influence of protein concentration and total solid content of heated milk on the formation of whey protein-casein complexes. The interactive effect of WP and $\mathrm{CN}$ in $\mathrm{CM}$ and $\mathrm{BM}$ yoghurts is conflicting showing a trend towards increased $\mathrm{pH}$ and decreased hardness in CM but opposite effects in BM (Table 3). It was discussed that some interactions between WP and $\mathrm{k}$-casein will make micelles less sensitive to $\mathrm{pH}$ decrease and enhance their solvation rather than their aggregation leading to weaker gels (Oldifield et al., 2000; González-Martínez et al., 2002).

This result suggest that decreasing the CN: WP ratio may significantly affect yoghurt rheology, which is in agreement with others who revealed that the ratio of proteins in the yoghurt formulations, not just increasing total solids 
Table 3: Model and estimated regression coefficients for the independent variables (casein and whey protein) and their significance in affecting yoghurt quality according to the model

Dependent variable $=$ constant $+C_{1}(W P)+C_{2}(C N)+C_{3}\left(W P^{*} W P\right)+C_{4}\left(C N^{*} C N\right)+C_{5}\left(W P^{*} C N\right)$

\begin{tabular}{|c|c|c|c|c|c|c|c|}
\hline \multirow[t]{2}{*}{ Dependent variables } & \multicolumn{6}{|c|}{ Coefficients for the independent variables } & \multirow[t]{2}{*}{ Model Significance } \\
\hline & Constant & $\mathrm{C}_{1}$ & $\mathrm{C}_{2}$ & $\mathrm{C}_{3}$ & $\mathrm{C}_{4}$ & $\mathbf{C}_{5}$ & \\
\hline \multicolumn{8}{|c|}{ Bovine milk yoghurts } \\
\hline Titrable acidity & $+0.685^{\star \star \star}$ & $+0.2^{* *}$ & $+0.151^{* *}$ & +0.08 & +0.034 & +0.039 & Significant $(p<0.05)$ \\
\hline $\mathrm{pH}$ & $+4.174^{\star \star \star}$ & $-0.102^{*}$ & +0.048 & -0.026 & +0.038 & -0.048 & Non-significant \\
\hline Hardness & $+74.8^{\star \star \star}$ & -0.43 & $+26.5^{\star}$ & +0.43 & +2.72 & +2.3 & Non-significant \\
\hline viscosity & $+604.8^{\star \star \star}$ & $+112.8^{\star \star}$ & $+193.2^{* *}$ & +62.9 & -29.7 & +94.8 & Highly significant $(p<0.005)$ \\
\hline G' & $+5885^{\star \star \star}$ & $+1068^{* *}$ & $+1840^{* *}$ & +606 & -314 & +887 & Highly significant $(p<0.005)$ \\
\hline G” & $+1334.5^{\star \star \star}$ & $+260.8^{\star *}$ & $+498.5^{\star *}$ & +159.7 & -19 & +215 & Highly significant $(p<0.005)$ \\
\hline $\operatorname{Tan} \delta\left(G^{\prime \prime} / G^{\prime}\right)$ & +0.226 & 0 & $+0.011^{* *}$ & +0.002 & $+0.006^{\star \star}$ & 0 & Highly significant $(p<0.005)$ \\
\hline \multicolumn{8}{|c|}{ Camel milk yoghurts } \\
\hline Titrable acidity & $+1.501^{\star \star \star}$ & -0.014 & $+0.109^{*}$ & -0.061 & +0.029 & -0.063 & Non-significant \\
\hline $\mathrm{pH}$ & $+3.925^{\star * *}$ & $+0.065^{\star *}$ & $+0.063^{* *}$ & -0.005 & -0.001 & +0.002 & Significant $(p<0.05)$ \\
\hline Hardness & $+21.433^{\star \star *}$ & $+5.262^{\star \star}$ & $+4.685^{\star *}$ & +0.815 & -0.06 & -0.167 & Highly significant $(p<0.000)$ \\
\hline Viscosity & $+123.6^{\star \star \star}$ & $+115.7^{\star \star}$ & $+54.3^{*}$ & +37.9 & -28.5 & +30.8 & Highly significant $(p<0.005)$ \\
\hline G' & $+1197^{\star \star \star}$ & $+1150^{\star *}$ & $+525^{\star}$ & +403 & -286 & +297 & Highly significant $(p<0.005)$ \\
\hline G” & $+290^{\star \star \star}$ & $+265.8^{\star \star}$ & $+129.7^{*}$ & +83 & -66.3 & +75.2 & Highly significant $(p<0.005)$ \\
\hline $\operatorname{Tan} \delta\left(G^{\prime \prime} / G^{\prime}\right)$ & $+0.242^{\star \star \star}$ & +0.004 & $+0.009^{* *}$ & $-0.008^{*}$ & -0.006 & 0 & Significant $(p<0.05)$ \\
\hline
\end{tabular}

Significance of the coefficients: ${ }^{*} p<0.05,{ }^{* *} p<0.01,{ }^{* * *} p<0.005$

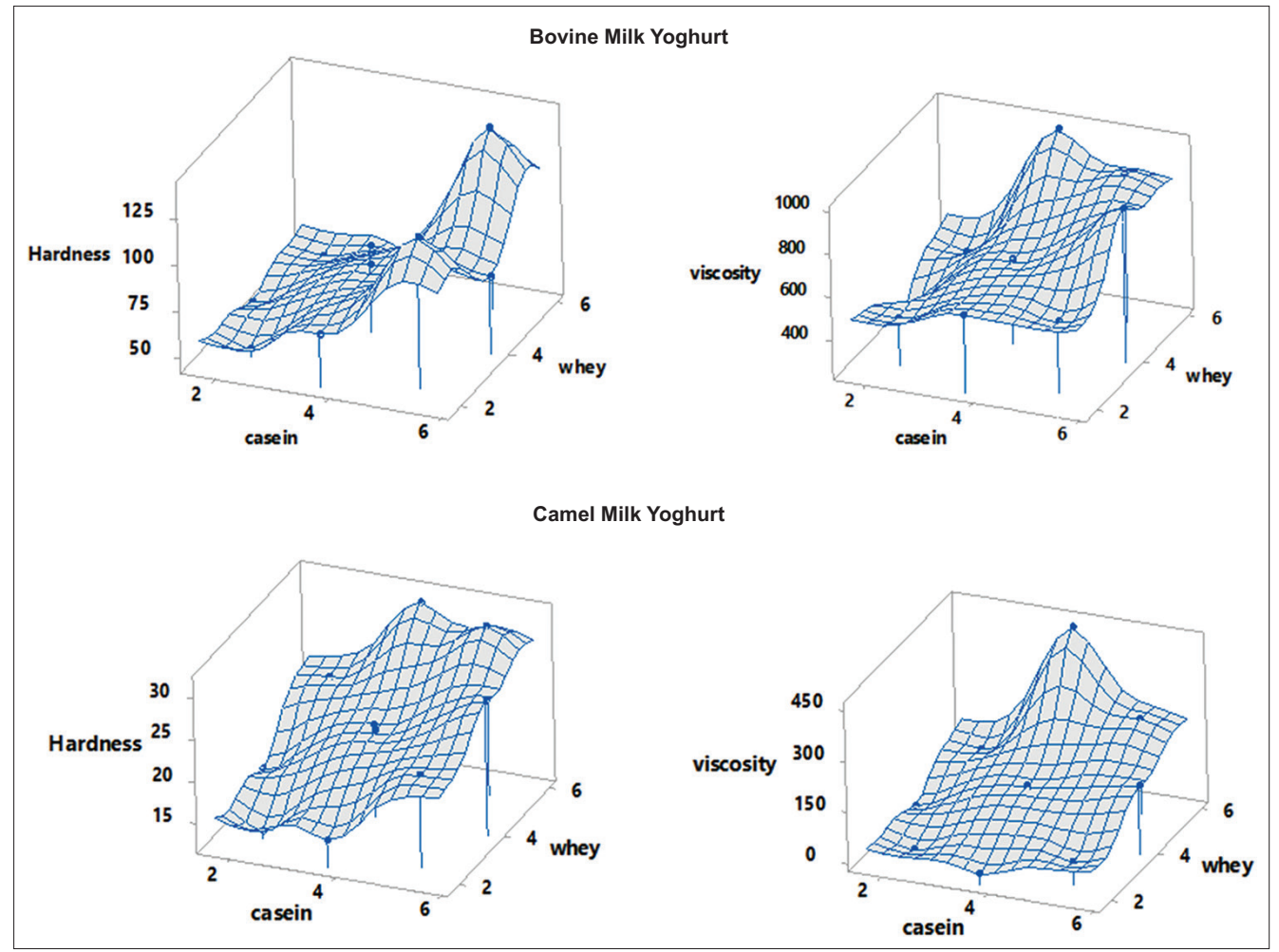

Fig 2. Surface plots showing interactive effects of WP and CN interactions on hardness and viscosity of bovine and camel milk yoghurt.

content, has a strong effect on yoghurt gel rheology and texture (Lobato-Calleros et al., 2004; Lucey et al., 1999; Sandoval-Castilla et al., 2004). The WPs have consistently shown improving effects on the rheological parameters of fortified $\mathrm{CM}$ and $\mathrm{BM}$ yoghurts (Table 3 and Fig. 3) supporting their participation in gel formation. This observation is well supported by the drastic increase in G' and G" values of CM yoghurts gels which was comparable to that of pure BM yoghurt gels, and shows an improvement in gel structure from liquid to solid like structure. The positive effect of addition of WP on yoghurt viscosity, firmness and gel strength $\left(G^{\prime}\right)$ and reduced syneresis have also been reported by many authors (e.g. Lucey et al., 1999; Bhullar et al., 2002; Haque and Ji, 2003; Remeuf et al., 2003; 


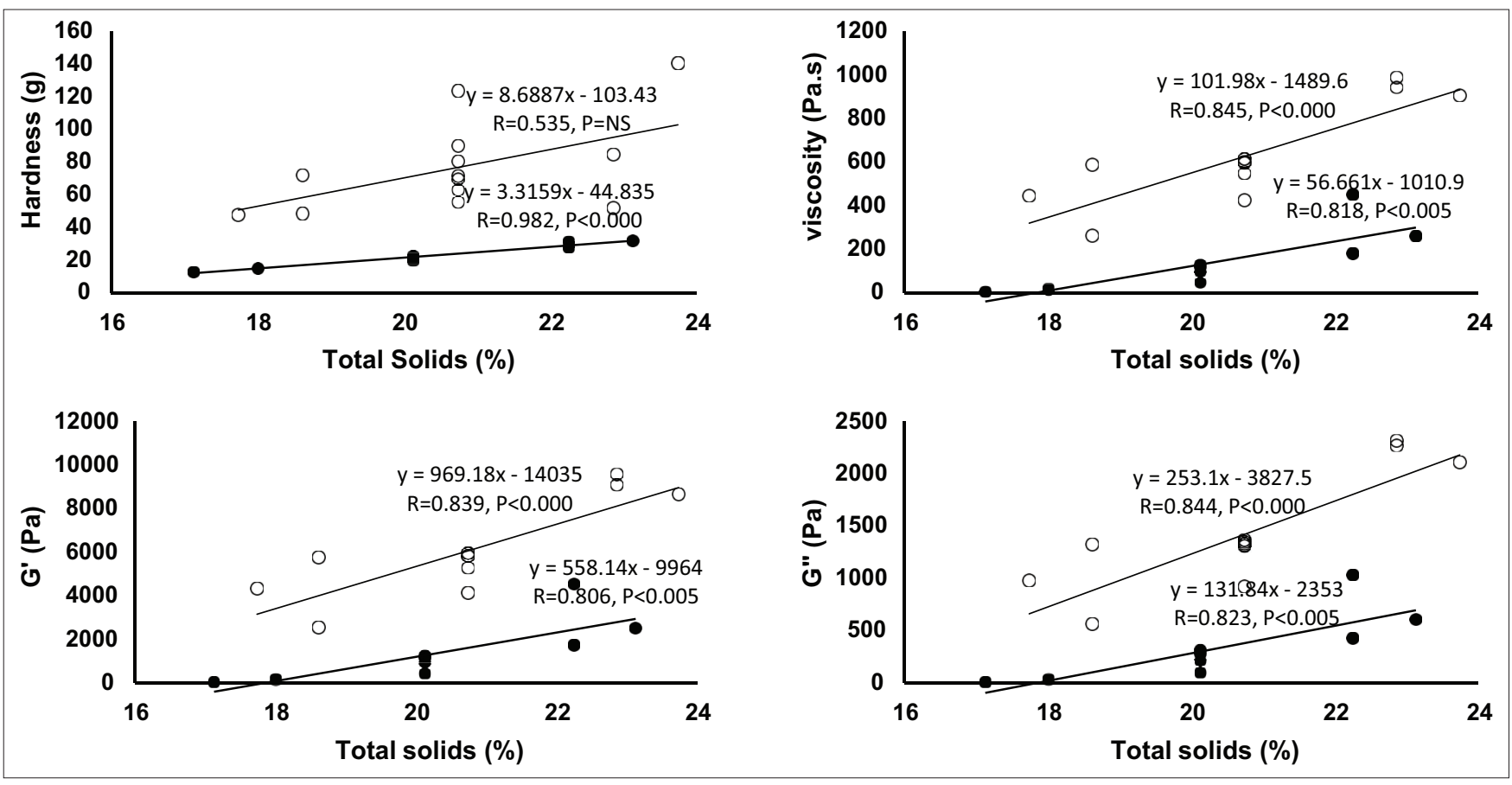

Fig 3. The effects of total solids (\%) on bovine milk and camel milk yoghurt hardness, viscosity, G' and G”. Bovine milk yoghurts (०) and camel milk yoghurts $(\bullet)$.

Isleten and Karagul-Yuceer, 2006; Tamime and Robinson, 2007; Lee and Lucey, 2010). In addition, increasing the WP: $\mathrm{CN}$ reduces the pores size and strengthens the gel network (Puvanenthiran et al., 2002). The negative effects of $\mathrm{CN}$ : CN interactions on viscosity, G' and G" of both the yoghurts (Table 3 ) are supported by previous reports (Smits and Van Brouwershaven, 1980; Noh et al., 1989) but cannot be precisely explained at this point. However, certain polymers may lead to self-association and suppression of cross complexes when present at high concentrations (Bungenberg, 1952, Burgess, 1994). In addition, increasing the ratio of other $\mathrm{CNs}$ ( $\alpha \mathrm{s}$ - and $\beta$-caseins) in milk may hinder the aggregation of $\mathrm{k}-\mathrm{CN}$ with the denatured WP. Moreover, Zhang et al. (2005) demonstrated that disordered milk CNs may have a "chaperone-like" effect that inhibits the unfolding of globular WPs and the development of heat induced CN: WP complexes via phosphoserine residues as well as hydrophobic surface interactions.

\section{CONCLUSIONS}

Yoghurt from pure camel milk has liquid consistency and weak gel structure compared with pure bovine milk yoghurt. Fortification with WP and $\mathrm{CN}$ was found to be a viable way to improve the texture and rheology of $\mathrm{CM}$ yoghurts. Stronger gel networks were produced in both $\mathrm{CM}$ and $\mathrm{BM}$ as a result of increased total solid and whey protein contents. The addition of bovine casein showed an optimal effect at the level of $2.5 \%$ suggesting negative interactions at higher concentrations. The model study presented in this papers allowed a logical description of the individual and interactive effects of WP and $\mathrm{CN}$ on the texture and rheology of fortified CM and BM yoghurts. More studies are needed to further understand the nature of the different complexes and how the gel structure of yoghurts can be optimized, e.g. by the addition of different hydrocolloids.

\section{ACKNOWLEDGEMENTS}

PhD student Huda Mohamed is thanked for the determination of endogenous casein and whey proteins in the milk powders used in this research. We thank BSc students Huda Alketbi, Muna Almeheiri, and Aysha Al Shamisi for technical assistance. The research was supported by UAEU funding for the UPAR project "Characterization of Camel Milk Proteins" (31F077, 2015).

\section{Author's contribution}

Kamal-Eldin, A. and Sobti, B. planned and supervised the research. Teneiji, H.A.A and Sobti, B. performed the experiments. Sobti, B. processed the data and wrote the manuscript along with Kamal-Eldin, A.

\section{REFERENCES}

Agrawal, R. P., S. Budania, P. Sharma, R. Gupta and D. K. Kochar 2007. Zero prevalence of diabetes in camel milk consuming Raica community of northwest Rajasthan, India. Diabetes Res. Clin. Pract. 76: 290-296. 
Al haj, O. A. and H. A. Al Kanhal. 2010. Compositional, technological and nutritional aspects of dromedary camel milk. Int. Dairy J. 2012: 811-821.

Al-Sheraji, S. H., A. Ismail, M. Y. Manap, S. Mustafa, R. M. Yusof and F. A. Hassan. 2013. Prebiotics as functional foods: A review. J. Funct. Foods. 5(4): 1542-1553.

Anema, S. G., S. K. Lee and H. Klostermeyer. 2006. Effect of protein, non-protein soluble components and lactose concentrations on the irreversible thermal denaturation of $\beta$-lactoglobulin and a-lactoalbumin in skim milk. J. Agric. Food Chem. 54: 7339-7348.

Attia, H., N. Kherouatou and A. Dhouib. 2001. Dromedary milk lactic acid fermentation: Microbiological and rheological characteristics. J. Ind. Microbiol. Biotechnol. 26: 263-270.

Ayoub, M. A., A. R. Palakkott, A. Ashraf and R. Iratni. 2018. The molecular basis of the anti-diabetic properties of camel milk. Diabetes Res. Clin. Pract. 146: 305-312.

Berhe, T., E. Seifu, R. Ipsen, M. Y. Kurtu and E. B. Hansen. 2017. Processing challenges and opportunities of camel dairy products. Int. J. Food Sci. 2017: 9061757.

Bhullar, Y. S., M. A. Uddin and N. P. Shah. 2002. Effects of ingredient supplementation on textural characteristics and microstructure of yoghurt. Milchwissenschaft. 57(6): 328-332.

Bungenberg, J. H. G. 1952. In: H. R. Kruyt (Ed.), Colloid Science. Ch. 10. Elsevier, New York.

Burgess, D. J. 1994. Complex coacervation: Microcapsule formation. In: P. Dubin, J. Bock, R. Davis, D. N. Schulz and C. Thies (ED.), Macromolecular Complexes in Chemistry and Biology, Springer, Berlin, pp. 285-300.

Costa, M. and C. A. Conte-Junior. 2015. Chromatographic methods for thedetermination of carbohydrates and organic acids in foods of animal origin. Compr. Rev. Food Sci. Food Saf. 14: 586-600.

Costa, M. P., B. S. Frasao, B. R. C. Lima, B. L. Rodrigues and C. A. Conte-Junior. 2016. Simultaneous analysis of carbohydrates and organic acids by HPLC-DAD-RI for monitoring goat's milk yogurts fermentation. Talanta. 152: 162-170.

Damin, M. R., M. R. Alcantara, A. P. Nunes and M. N. Oliveira. 2009. Effects of milk supplementation with skim milk powder, whey protein concentrate and sdium caseinate on the acidification kinetics, rheological properties and structure of nonfat stirred yoghurt. LWT Food Sci. Technol. 42(10): 1744-1750.

Donato, L. and H. F. Guyomarc. 2009. Formation and properties of the whey protein/kappa-casein complexes in heated skim milk a review. Dairy Sci. Technol. 89: 3-29.

El-Agamy, E. I., M. Nawar, S. M. Shamsia, S. Awad and G. Haenlein. 2009. Are camel milk proteins convenient to the nutrition of cow milk allergic children? Small Rumin. Res. 82: 1-6.

Ghnimi, S. and A. Kamal-Eldin. 2015. Casein variants and challenges in the valorization of camel milk as a healthy alternative to cow milk. J. Bioequivalence Bioavailab. 7: e67.

González-Martínez, C., M. Becerra, M. Cháfer, A. Albors, J. M. Carot and A. Chiralt. 2002. Influence of substituting milk powder for whey powder on yoghurt quality. Trends Food Sci. Technol. 13: 334-340.

Haque, Z. U. and T. Ji. 2003. Cheddar whey processing and source: II. Effect on non-fat ice cream and yoghurt. Int. J. Food Sci. Technol. 38: 463-473.

Herrero, A. M. and Requena, T. 2006. The effect of supplementing goat milk with whey protein concentrates on textural properties of set type yogurts. Int. J. Sci. Technol. 41: 87-92.

Isleten, M. and Karagul-Yuceer, Y. 2006. Effects of dried dairy ingredients on physical and sensory properties of Nonfat Yogurt. J. Dairy Sci. 89: 2865-2872.
Kamal, M., M. Foukani and R. Karoui. 2017. Rheological and physical properties of camel and cow milk gels enriched with phosphate and calcium during acid-induced gelation. J. Food Sci. Technol. 54: 439-446.

Kappeler, S. 1998. Compositional and Structural Analysis of Camel Milk Proteins with Emphasis on Protective Proteins. Ph.D. Thesis, Swiss Federal Institute of Technology, Zurich, Switzerland, pp. 59-62.

Kappeler, S., Z. Farah and Z. Puhan. 1998. Sequence analysis of Camelus dromedarius milk caseins. J. Dairy Res. 65(2): 209-222.

Lee, W. J. and Lucey, J. A. 2010. Formation and physical properties of Yogurt. Asian Australas. J. Anim. Sci. 23: 1127-1136.

Lobato-Calleros, C., O. Martínez-Torrijos, O. P. Sandoval-Castilla, J. P. erez-Orozco and E. J. Vernon-Carter. 2004. Flow and creep compliance properties of reduced fat yoghurts containing protein-based fat replacers. Int. Dairy J. 14: 777-782.

Lucey, J. A., P. A. Munro and H. Singh. 1999. Effects of heat treatment and whey protein addition on the rheological properties and structure of acid skim milk gels. Int. Dairy J. 9: 275-279.

Lucey, J. A., M. Tamehana, H. Singh and P. A. Munro. 1998. Effect of interactions between denatured whey proteins and casein micelles on the formation and rheological properties of acid skim milk gels. J. Dairy Res. 65: 555-567.

Magjeed, N. A. 2005. Corrective effect of milk camel on some cancer biomarkers in blood of rats intoxicated with aflatoxin B1. J. Saudi Chem. Soc. 9: 253-263.

Marafon, A. P., A. Sumi, D. Granato, M. R. Alcantara, A. Y. Tamine and M. Nogueira de Oliveira. 2011. Effects of partially replacing skimmed milk powder with dairy ingredients on rheology, sensory profiling, and microstructure of probiotic stirred-type yogurt during cold storage. J. Dairy Sci. 94: 5330-5340.

Mirmiran, P., H. D. Ejtahed, P. Angoorani, F. Eslami and F. Azizi. 2017. Camel milk has beneficial effects on diabetes mellitus: A systematic review. Int. J. Endocrinol. Metab. 15(2): e42150.

Mohamed, M. A., M. Larssonraznikiewicz and M. U. Mohamud. 1990. Hard cheese making from camel milk. Milchwissenschaft. 45: 716-718.

Noh, B., T. Richardson and L. K. Creamer. 1989. Radiolabelling of the heat induced interactions between $\beta$-lactoglobulin and k-casein in milk and in buffer solutions. J. Food Sci. 54: 889-893.

Oldfield, D. J., H. Singh and M. W. Taylor. 1998. Association of $\beta$-lactoglobulin and $\alpha$-lactalbumin with the casein micelles in the skim milk heated in an ultra-high temperature plant. Int. Dairy J. 8(9): 765-770.

Peng, Y., M. Serra, D. S. Horne and J. A. Lucey. 2009. Effect of fortification with various types of milk proteins on the rheological properties and permeability of nonfat set yogurt. J. Food Sci. 74: 666-673.

Prasanna, P. H. P., A. S. Grandison and D. Charalampopoulos. 2013. Microbiological, chemical and rheological properties of low fat set yoghurt produced withexopolysaccharide (EPS) producing bifidobacterium strains. Food Res. Int. 51: 15-22.

Puvanenthiran, A., R. P. W. Williams and M. A. Augustin. 2002. Structure and visco-elastic properties of set yoghurt with altered casein to whey protein ratios. Int. Dairy J. 12: 383-391.

Quan, S., H. Tsuda and T. Miyamoto. 2008. Angiotensin I-converting enzyme inhibitory peptides in skim milk fermented with Lactobacillus helveticus 130B4 from camel milk in Inner Mongolia, China. J. Sci. Food Agric. 88: 2688-2692.

Remeuf, F., S. Mohammed, I. Sodini and J. P. Tissier. 2003. Preliminary observations on the effects of milk fortification and heating on microstructure and physical properties of stirred 
yogurt. Int. Dairy J. 13: 773-782.

Roefs, S. P. F., A. E. A. De Groot-Mostert and T. Van Vliet. 1990. Structure of acid casein gels 1 . Formation and model of gel network. Colloids Surf. 50: 141-159.

Sandoval-Castilla, O., C. Lobato-Calleros, E. Aguirre-Mandujano and E. J. Vernon-Carter. 2004. Microstructure and texture of yoghurt as influenced by fat replacers. Int. Dairy J. 14: 151-159.

Séverin, S. and X. Wenshui. 2005. Milk biologically active components as nutraceuticals: Review. Crit. Rev. Food Sci. Nutr. 45: 645-656.

Shamsia, S. M. 2009. Nutritional and therapeutic properties of camel and human milks. Int. J. Genet. Mol. Biol. 1: 52-58.

Smits, P. and J. H. Van Brouwershaven. 1980. Heat induced association of $\beta$-lactoglobulin and casein micelles. J. Dairy Res. 47: 313-325.
Sodini, I. and C. Béal. 2003. Fabrication des yaourts et lait fermentés. Tech. Lingénieur. 6315: 1-31.

Tamime, A. Y. and R. K. Robinson. 2007. Tamime and Robinson's Yoghurt Science and Technology. $3^{\text {rd }}$ (Ed.), CRC Press Woodhead, Cambridge, UK.

Technavo. 2018. Global Camel Milk Market 2018-2022 Trends, Drivers, and Challenges, Industrial Report, No. 118.

van Vliet, T., H. J. M. Van Dijk, P. Zoon and P. Walstra. 1991. Relation between syneresis and rheological properties of particle gels. Colloids Polym. Sci. 269(6): 620-627.

Zhang, X., X. Fu, H. Zhang, C. Liu, W. Jiao and Z. Chang. 2005. Chaperone-like activity of $\beta$-casein. Int. J. Biochem. Cell Biol. 37(6): 1232-1240. 